\title{
Estimativa do Prazo Comercial de Piraputanga (Brycon microleps) Eviscerada e Estocada em Gelo
}

\author{
Daniel Oster Ritter (I,II,III), Marilu Lanzarin (I,II,III), Edivaldo \\ Sampaio de Almeida Filho (II), Edivaldo Sampaio de Almeida Filho \\ (II), Eliane Teixeira Mársico (I), Monica Queiroz de Freitas (I) \\ (I) UFF - Universidade Federal Fluminense (R. Vital Brazil Filho, $n^{\circ}$ 64, Niterói - RJ), (II) UFMT \\ - Universidade Federal de Mato Grosso (Av. Fernando Correa da Costa, $n^{\circ} 2.367$, Boa \\ Esperança, Cuiaba- MT), (III) IFMT - Instituto Federal de Mato Grosso (Av. Tancredo Neves, \\ Sorriso, MT)
}

\section{Resumo}

O prazo comercial de um alimento é um termo utilizado para designar o período de tempo no qual este conserva as suas características de qualidade e as respectivas garantias de segurança alimentar, podendo ser estimado através de análises bacteriológicas e físico-químicas. O objetivo deste trabalho foi determinar o prazo comercial de piraputanga (Brycon microleps) durante estocagem em gelo através de análises bacteriológicas e físico-químicas. Foram coletados 45 exemplares, com aproximadamente $0,9 \mathrm{~kg}$ cada, que foram eviscerados e acondicionados em caixas isotérmicas contendo gelo em escamas na proporção de 1:1. As análises foram realizadas a cada dois dias até o oitavo dia de estocagem, sendo posteriormente feitas diariamente até o $18^{\circ}$ dia de estocagem. Estas consistiram na quantificação de bactérias heterotróficas aeróbias mesófilas (BHAM), de bactérias heterotróficas aeróbias psicrotróficas (BHAP) e de bactérias do gênero Aeromonas. Quanto as determinações físico-químicas, foram realizadas a análise de $\mathrm{pH}$ utilizando um o método potenciométrico e a quantificação das bases voláteis totais (BVT) utilizando o método de Conway. As contagens de BHAM, BHAP e do gênero Aeromonas spp variaram de 1,46 Log UFC/g, 1,02 Log UFC/g e 1,10 Log UFC/g no dia zero à 6,18 Log UFC/g, 9,05 Log UFC/g e 8,57 Log UFC/g no $18^{\circ}$ dia de estocagem respectivamente. A legislação nacional não contempla limites

\footnotetext{
Referência:

Daniel Oster Ritter, Marilu Lanzarin, Edivaldo Sampaio de Almeida Filho, Edivaldo Sampaio de Almeida Filho, Eliane Teixeira Mársico, Monica Queiroz de Freitas. Estimativa do Prazo Comercial de Piraputanga (Brycon Microleps) Eviscerada e Estocada em Gelo. In: Anais do 12 Congresso Latinoamericano de Microbiologia e Higiene de Alimentos - MICROAL 2014 [= Blucher Food Science Proceedings, num.1, vol.1]. São Paulo: Editora Blucher, 2014.

DOI 10.5151/foodsci-microal-225
} 
para contagem de bactérias aeróbias, no entanto pesquisadores utilizam um padrão internacional de $7 \mathrm{Log}$ UFC/g, que neste experimento foi alcançado no $15^{\circ}$ dia de estocagem. Por mais que as bactérias do gênero Aeromonas spp não sejam citadas em padrões nacionais ou internacionais, sua contabilização se torna extremamente importante por ser uma bactéria de habitat predominantemente aquático e pelo fato de existir espécies altamente patogênicas aos humanos. As variações de valores de $\mathrm{pH}$ e BVT foram de 6,31 no dia zero a 6,9 no $18^{\circ}$ dia de estocagem e de $10,15 \mathrm{mg}$ de $\mathrm{N} / 100 \mathrm{~g}$ no dia zero a $14,7 \mathrm{mg}$ de $\mathrm{N} / 100 \mathrm{~g}$ no $18^{\circ}$ dia de estocagem, respectivamente. A legislação brasileira determina como limite máximo de $\mathrm{pH}$, o valor de 6,5, que neste experimento foi alcançado no $10^{\circ}$ dia de estocagem. Em relação ao BVT, utiliza-se o limite de $30 \mathrm{mg}$ de N/100 g, valor este que não foi alcançado durante o período de estocagem. Levandose em consideração os dados obtidos, conclui-se que o prazo comercial estimado da piraputanga eviscerada estocada em gelo é de 10 dias.

Palavras-Chave: Deterioração, Qualidade, Frescor

Agência de Fomento: CAPES - Coordenação de Aperfeiçoamento de Pessoal de Nível Superior 